\title{
Brain Abscess due to Pasteurella multocida
}

\author{
Zhong Xing LI, Baozhen ZHAO and Zhanqin FENG \\ Bacteriological Laboratory, The Second Affillated Hospital, HeBei Medical College, \\ Shijiazhuang, China \\ (Received: September 10, 1993) \\ (Accepted: November 4, 1993)
}

Key words: Pasteurella multocida, brain abscess

\begin{abstract}
The patient was a 26-year-old man who complained of headache and vomiting. On examination, there was nothing abnormal, but the edge of the right optic papilla was not clear. His temperature was $38.5^{\circ} \mathrm{C}$, pulse $96 / \mathrm{min}$, blood pressure $120 / 80 \mathrm{mmHg}$. A space-occupying lesion in his fronto-dextra cupular part was found by CT scanning. He had a 12-year history of chronic purulent otitis. The diagnosis was a brain abscess in the fronto-dextra cupular part. The brain abscess was extracted and Pasteurella multocida was isolated from the dark brown pus draining from the abscess. The patient recovered through proper antibiotic therapy based on a sensitivity test. Reports of infections caused by this organism in foreign countries very widely from local infections due to bites and scratches by cats, dogs etc. to general infections such as infections of the respiratory tract, sepsis and meningitis. However, Pasteurella multocida brain abscesses are rare.

Pasteurella multocida is a Gram-negative short rod which is best known as part of the mouth flora and as a pathogen causing septicemia in many domestic animals, such as cats, dogs etc. ${ }^{1)}$. Infection in man results mainly from animal bites or scratches. It has been reported that Pasteurella multodida can cause human septicemia, meningitis, respiratory tract infection, conjunctivitis and other infections. We isolated a strain of Pasteurella multocida from the pus of a brain abscess following chronic purulent otitis on August $6,1990$.
\end{abstract}

\section{Case Report}

A 26-year-old man was admitted to our hospital on June 7, 1990, with the chief complaints of headache and vomiting. He had a 12 -year history of chronic purulent otitis.

The temperature was $38.5^{\circ} \mathrm{C}$, pulse $96 / \mathrm{min}$, blood pressure $120 / 80 \mathrm{mmHg}$. The results of physical examination were normal, but the edge of the right optic papilla was not clear. A space-occupying lesion in the fronto-dextra cupular part of the patient was found by CT scanning. Routine blood analysis revealed hemoglobin $12.5 \mathrm{~g} / \mathrm{dl}$, white blood cell count $9,900 / \mu 1$, bleeding time $1 \mathrm{~min}$ and coagulating time $1 \mathrm{~min}$. Liver function tests revealed thymol turbidity test $14.2 \mathrm{U}$, zinc turbidity test $24 \mathrm{U}$ and positive $\mathrm{HBs} \mathrm{Ag}$. The diagnosis was a brain abscess in right frontal cupular part.

The brain abscess was extracted on June 8,1990 . It measured $6 \times 5 \times 4 \mathrm{~cm}$. The pus from the abscess was dark brown and adhesive. But did not have a foul odor. The pus was cultured and Pasteurella multocida was found. $200 \mathrm{mg}$ of ampicillin and $30 \mathrm{mg}$ chloramphenicol per $\mathrm{Kg}$ per day (intravenously

\footnotetext{
別刷請求先：Li ZHONG XING

Hebei Provincial Center for Clinical

Laboratory, Second Hospital of Hebei

Medical College, Shijiazhuang, China
} 
guttae) for 14 days (8-21 June, 1990). $5 \mathrm{mg}$ of gentamycin per $\mathrm{Kg}$ per day (iv gtt) for 7 days (22-28 June, 1990). $100 \mathrm{mg}$ of ampicillin and 30mg of chloramphenicol per Kg per day (iv gtt) for 15 days (29 June-13 July 1990). The patient recovered through antibiotic therapy based on a sensitivity test and was discharged on July 24 .

\section{Isolation and Identification}

The pus was streaked on a blood agar plate according to the routine method. After 18-24 hours of incubation at $35^{\circ} \mathrm{C}$, round, nonhomolytic, gray colonies, $0.5-1.5 \mathrm{~mm}$ in diameter appeared. Gram's stain revealed small Gram-negative rods and flagella staining showed there were no flagella.

The characteristics of the isolate were as follows: positive reactions for oxidase and catalase; absence of growth on MacConkey medium and SS agar an acid butt without gas and an alkaline slant on Kligler iron agar, and fermentation of glucose without gas.

Based on the above characteristics, the organism probably belonged to the genus Pasteurella and was tentatively considered to be Pasteurella multocida in the light of reference ${ }^{2}$.

A series of biochemical tests were performed to further identify the organism (Table 1).

In 1981, Oberhofer divided Pasteurella multocida into 11 biotypes $^{3)}$. Our isolate was biotype A.

In 1985, Mutters et al. made a taxonomically great change in which the geuns Pasteurella was extended from 6 species to a total of 11 species, and Pasteurella multocida was subdivided into 3 subspecies, Pasteurella multocida subsp. multocida, Pasteurella multocida subsp. septica and Pasteurella multocida subsp. gallicida ${ }^{4}$, The characteristics of the three subspecies are presented in Table 2 and our isolate fell into Pasteurella multocida subsp. multocida.

The pathogenicity of the isolate was determined by intraperitoneally injecting a white mouse with 0.2 $\mathrm{ml}$ of suspension of the organism. The animal died after 24 hours and Pasteurella multocida was readily recovered from the heart blood, liver and spleen.

Antibiotic sensitivity was tested by the Kirby-Bauer disc method. The results showed that the isolate was sensitive to penicillin, ampicillin, erythromycin, kanamycin, tetracycline, chloramphenicol, medemycin, gentamicin and methicillin and resistant to vancomycin.

Table 1 Biochemical characteristics of Pasteurella multocida

\begin{tabular}{lclc}
\hline \multicolumn{1}{c}{ Test } & Reaction & \multicolumn{1}{c}{ Test } & Reaction \\
\hline Hemolysis & - & DNase & - \\
Oxidase & + & ONPG & - \\
Catalase & + & Growth on & - \\
Motility & - & MacConkey & \\
Indole & + & Acid from : & \\
MR & - & Glucose & + \\
VP & - & Lactose & - \\
Citrate & - & Sucrose & + \\
Urea & - & Maltose & + \\
Nitrate & + & Mannitol & + \\
reduction & & Xylose & + \\
Gelatin & - & Fructose & + \\
L-lysine & - & Salicin & - \\
L-arginine & + & Sorbitol & + \\
Starch & - & Trehalose & + \\
Esculin & - & Inositol & - \\
\hline
\end{tabular}

Table 2 Biochemical characteristics of the three subspecies of Pasteurella multocida

\begin{tabular}{|c|c|c|c|c|c|c|c|c|c|c|}
\hline & 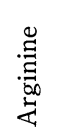 & $\begin{array}{l}\stackrel{0}{\circ} \\
\stackrel{0}{\Xi}\end{array}$ & $\stackrel{\mathscr{D}}{\varpi}$ & 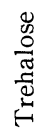 & 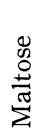 & $\begin{array}{l}0 \\
0 \\
\frac{0}{2} \\
\frac{\lambda}{x}\end{array}$ & 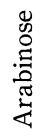 & 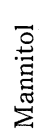 & 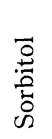 & $\frac{\overrightarrow{0}}{\frac{0}{3}}$ \\
\hline \multicolumn{11}{|l|}{$\begin{array}{l}\text { P. multocida } \\
\text { subsp.: }\end{array}$} \\
\hline multocida & + & + & - & $\mathrm{d}$ & - & $\mathrm{d}$ & - & + & + & - \\
\hline septica & + & + & - & + & - & + & - & + & - & - \\
\hline gallicida & + & + & - & - & - & + & $\mathrm{d}$ & + & + & + \\
\hline
\end{tabular}




\section{Discussion}

In 1980, Pasteur first isolated the etiological agent of fowl cholera, Pasteurella multocida, and characterized it morphologically and biochemically.

The first reported case in a human, a farmer's wife with puerperal fever, was described in 1913 by Brugnatelli, who isolated the rod from the patient's blood and proved it to be Pasteurella multocida. In 1930, Kapel and Holm first described Pasteurella multocida infection resulting from a cat bite, and from then on there have been increasing numbers of reports of human infections caused by Pasteurella multocida, such as bacteremia, septicemia, septicemic arthritis, meningitis, pyencephalus, urinary tract infection, bronchitis, pneumonia and conjunctivitis ${ }^{5 / 27}$.

Reports of human brain abscess caused by Pasteurella multocida are rare so far, only a few cases world wide and none in China ${ }^{5,8,9)}$. The present patient had a history of close exposure to cats and dogs since he and his neighbours all had fed those pets. The patient had suffered from chronic purulent otitis and had been getting worse in the past two years, often with secretion of pus.

Pasteuerlla multocida can be isolated from the digestive and respiratory tracts of cats, dogs, mice, rabbits, cattle, sheep, pigs etc. Rates of carriage of Pasteurella multocida in the oral or nasal secretions of the animals are quite high, $70-90 \%$ in cats, $50-66 \%$ in dogs, $51 \%$ in pigs and $14 \%$ in Norwegian rats. Pasteurella multocida is a pathogen of many species of animals. Human infection most often follows cat and dog bites or scratches. Yet infection also can result from the bites of other animals, including the opossum, rat, lion, rabbit, pig and wolf, and even from the kick of a horse. Therefore, a person who raises cats and dogs etc. should be careful not to be bitten or scratched and exposed to oral secretions as far as possible. Once bitten or scratched by the above animals, the patient should have the local wound treated with antibiotics to prevent infection with Pasteurella multocida.

\section{References}

1) Arashima, Y., Kubo, N., Iwasaki, Y., et al.: Human Respiratory Tract Infection by Pasteurella multocida subsp. multocida Presumably Derived from the Cat. J. J. A. Inf. D., 64: 1200-1204, 1990.

2) Krieg, N.R. \& Holt, J.C.: Bergey's Manual of Systematic Bacteriology. Vol. 1. Baltimore: Williams \& Wilkins 1984: 552.

3) Oberhofer, T.R.: Characteristics and biotypes of Pasteurella multocida isolated from human. J. Clin. Microbiol. 13(3): $566,1981$.

4) Mutters, R., et al.: Reclasification of the Genus Pasteurella Trevisan 1887 on the basis of deoxyribonucleic acid homology, with proposals for the new species $P$. dagmatis, P. canis, P. stomatis, P. anatis, and P. langaa. Int. J. Syst. Bacterial. 35: 309, 1985.

5) Weber, D.J., et al.: Pasteurella multocida infections. Medicine. 63(2): 133, 1984.

6) Johnson, R.H., et al.: Unusual infections caused by Pasteurella multocida. JAMA 237: 146, 1977.

7) Mcnamara, M.P., et al.: Ocular infections secondary to Pasteurella multocida. Am. J. Ophthalmol. 106: 133, 1988.

8) Klein, D.M., et al.: Pasteurella multocida brain abscess following perforating cranial dog bite. J. Pediatr. 92(4): 588, 1978.

9) Whittle, I.R. \& Besser, M.: Otogenic Pasteurella multocida brain abscess and glomus jugulare tumor. Surg. Neurol. 17(1): 4, 1982. 


\title{
Pasteurella multocida による脳膿瘍の 1 例
}

\author{
中国河北医学院第二医院細菌室 \\ 李 仲興趙 宝珍 馮占琴 \\ (平成 5 年 9 月 10 日受付) \\ (平成 5 年 11 月 4 日受理)
}

要旨

12 年間にわたる慢性化膿性中耳炎の 26 歳の男性 が頭痛及び嘔吐にて来院した。頭部 CTにて右前 頭部に膿瘍を認めた。膿瘍摘出術施行し, 膿瘍の 培養では Pasteurella multocida が摘出された。本
患者は感受性試験に基づいた適切な抗生剤の投与 により治癒した。 P. multocidaによる感染症は猫 や犬にかまれた後の局所の感染から呼吸器感染 症, 敗血症および髄膜炎があるが, 脳膿瘍は珍し く，報告した。 